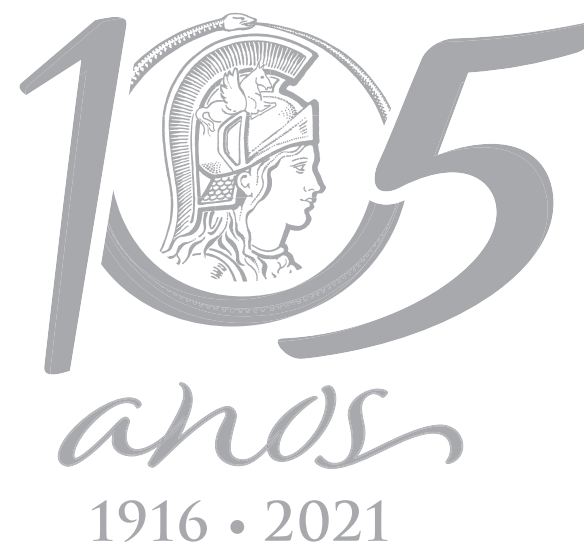

\title{
Addition of L-Glutamine + Glutamic Acid and L-Arginine to the diet of weaned piglets
}

\author{
DAVID R.P. DA SILVA, LEONARDO A.F. PASCOAL, APARECIDA DA C. OLIVEIRA, \\ TEREZINHA D.D. MARTINS, JOSÉ H.V. DA SILVA, FLÁVIO G. FERNANDES \& \\ JONATHAN M. DOS S. ALMEIDA
}

\begin{abstract}
This study aimed to evaluate the supplementation of L-glutamine + glutamic acid and/or L-arginine on the productive performance, incidence of diarrhea, intestinal morphological of weaned piglets. Sixty-four 28-day-old weaned piglets were distributed in four treatments: DC - control diet; DG - glutamine diet (1\% L-glutamine + glutamic acid); DA - arginine diet (1\% L-arginine); and DGA - glutamine + arginine diet $(0.5 \%$ L-glutamine + glutamic acid and $0.5 \%$ L-arginine) with eight replicates and two animals per experimental unit. The addition of $1 \% \mathrm{~L}$-arginine to the piglet diet improved weight gain and feed conversion over 28 to 35 days of age. In the period of 28 to 49 days of age, supplementation with $1 \%$ L-glutamine + glutamic acid increased the animals' weight gain and reduced the incidence of diarrhea. Supplementation with amino acids in combination had a positive effect on the morphometric parameters of the intestinal mucosa compared to the control diet. Supplementation with $1 \%$ L-glutamine + glutamic acid increased the number of anti-PCNA ${ }^{+}$cells and goblet cells. Taken together, our findings suggest that supplementation with L-glutamine + glutamic acid and L-arginine can improve the productive performance and enhance the integrity of the intestinal mucosa of weaned piglets.
\end{abstract}

Key words: cell proliferation, functional amino acid, intestinal morphology, weaning.

\section{INTRODUCTION}

The maintenance of intestinal health is important to minimize or prevent low performance, morbidity and susceptibility to enteric infections in early-weaned piglets since the functional development of the gastrointestinal tract which includes the development of enterocytes, mucosa, microbiota and the intestinal immune system is directly related to the performance of the animals (Liu et al. 2020). Certain morphological alterations of the small intestine of the piglets, evidenced by reduced villus height and increased crypt depth, lead to a lower number of absorptive cells and a higher number of secretory cells, which are associated with a decrease in voluntary intake and nutrient absorption (Ji et al. 2019, Zou et al. 2019). Thus, food ingredients commonly used to promote the establishment of intestinal health in piglets, such as dairy products and other ingredients of animal origin, are costly, and the use of antibiotics as growth promoters has been restricted in animal production. Thus, there is a need to search for new technologies or food ingredients that promote the effective functioning of the gastrointestinal tract of the animals and favor good performance.

Recent findings have indicated additional functions for some amino acids in the gastrointestinal tract, improving the digestion and absorption of nutrients as well as enhancing the immune system of weaned piglets (Freire et al. 2019, Xiong et al. 2019, He et 
al. 2019). Among these are L-glutamine, glutamic acid and L-arginine, substances with trophic action on the intestinal mucosa and on the immune system. L-glutamine and glutamic acid, when present in the intestinal lumen of the animals, directly promote the differentiation of enterocytes since they increase the production of polyamines through the expression of the ornithine decarboxylase gene, favoring the proliferation and the maturation of the cells of the gastrointestinal tract (Duttlinger et al. 2020, Mou et al. 2019). L-arginine is considered a conditionally essential amino acid for young animals, who have particularly high requirements of this amino acid for growth and metabolic functions. L-arginine deficiency can lead to a low synthesis of citrulline and consequently ornithine, which can delay animal growth and decrease the proliferation of enteric cells (Wu et al. 2007). In this context, it is necessary to assess the (combined or individual) actions of these two conditionally essential amino acids that have trophic effects to maintain the integrity and intestinal development of animals after weaning, which is considered a critical stage in pig production.

The aim of this study was to evaluate the effect of L-glutamine + glutamic acid and L-arginine separately and in combination on the productive performance, incidence of diarrhea, intestinal morphometry and anti-PCNA ${ }^{+}$cell count in the duodenum of weaned piglets.

\section{MATERIALS AND METHODS}

The experiment was carried out at the Pig Farming Laboratory of the Animal Science Department of the Center for Human, Social and Agricultural Sciences of the Federal University of Paraíba, Campus III, located in the city of Bananeiras, state of Paraíba (PB), Brazil. The project was approved by the Federal University of Paraíba Animal Ethics Committee with a certificate issued under protocol number 0405/14.

\section{Animals, experiment design and treatments}

A total of 64 animals to the same commercial lineage (Agroceres ${ }^{\oplus}$ ) were used, 32 barrows and 32 females, weaned at 28 days of age with a mean initial weight of $6.12 \pm 0.62 \mathrm{~kg}$. The animals were housed in suspended nursery pens ( $1.5 \mathrm{~m}$ by 2.0 $\mathrm{m}$ ) with slatted plastic flooring, equipped with semi-automatic feeding and drinking troughs, located in a masonry shed. During the first 20 days of the experimental period, 100-W incandescent bulbs were used to warm the piglets. The maximum and minimum temperatures and the relative humidity of the air were measured three times a day, at 7:00 a.m., 12:00 p.m. and 5:00 p.m., with a thermohygrometer. The mean maximum and minimum temperatures recorded were $29.8^{\circ} \mathrm{C}$ and $24.1^{\circ} \mathrm{C}$, with average values of $68.3 \%$ and $52.8 \%$ for maximum and minimum relative humidity of the air, respectively.

The animals were distributed in a randomized complete block design using the initial weight as a criterion for forming the blocks. The design consisted of four treatments with eight replicates and two animals per experimental unit, one male and one female. The treatments were as follows: DC - control diet, composed mainly of corn, soybean meal and dairy product, without supplementation of L-glutamine + glutamic acid and L-arginine; DG - glutamine diet consisting mainly of corn, soybean meal and dairy product supplemented with $1 \%$ L-glutamine + glutamic acid; DA - arginine diet consisting mainly of corn, soybean meal and dairy product supplemented with $1 \%$ L-arginine and DGA - glutamine + arginine diet consisting mainly of corn, soybean meal and dairy product supplemented with $0.5 \%$ L-glutamine + glutamic acid and $0.5 \%$ L-arginine. The feeds were formulated (Tables I, II and III) to meet the nutritional recommendations proposed by Rostagno et al. (2011) for pigs with high genetic potential. The diets were isoenergetic and isoproteic based on the weight range of the animals. No growth promoters were added to the diets. During the experimental period the animals received water and feed ad libitum. 
Table I. Formulation and chemical composition of experimental diets used for piglets weighing 5-9 $\mathrm{kg}^{\mathrm{a}}$.

\begin{tabular}{|c|c|c|c|c|}
\hline \multirow[b]{2}{*}{ Ingredients (kg) } & \multicolumn{4}{|c|}{ Experimental diets $^{\mathrm{d}}$} \\
\hline & CD & GD & $A D$ & GAD \\
\hline Corn meal & 51.04 & 54.18 & 57.04 & 55.61 \\
\hline Soybean meal & 29.46 & 27.51 & 23.80 & 25.66 \\
\hline Whey powder & 8.59 & 8.00 & 8.00 & 8.00 \\
\hline Soybean oil & 5.50 & 4.74 & 5.34 & 5.04 \\
\hline Calcitic lime & 0.75 & 0.76 & 0.77 & 0.76 \\
\hline Dicalcium phosphate & 1.57 & 1.60 & 1.63 & 1.62 \\
\hline L-glutamine + glutamic acid & 0.00 & 1.00 & 0.00 & 0.50 \\
\hline L-arginine & 0.00 & 0.00 & 1.00 & 0.50 \\
\hline L-lysine HCL & 0.70 & 0.76 & 0.87 & 0.82 \\
\hline DL-methionine & 0.28 & 0.30 & 0.32 & 0.30 \\
\hline L-tryptophan & 0.05 & 0.06 & 0.09 & 0.08 \\
\hline L-threonine & 0.31 & 0.34 & 0.39 & 0.37 \\
\hline Mineral and vitamin suppl.b & 0.50 & 0.50 & 0.50 & 0.50 \\
\hline Common salt & 0.17 & 0.18 & 0.18 & 0.18 \\
\hline $\mathrm{BHT}$ & 0.02 & 0.02 & 0.02 & 0.02 \\
\hline Inert $^{\mathrm{C}}$ & 1.00 & 0.00 & 0.00 & 0.00 \\
\hline Total & 100.0 & 100.0 & 100.0 & 100.0 \\
\hline \multicolumn{5}{|c|}{ Calculated values (\%) } \\
\hline Metabolizable energy (Mcal/kg) & 3.400 & 3.400 & 3.400 & 3.400 \\
\hline Crude protein & 20.00 & 20.00 & 20.00 & 20.00 \\
\hline Calcium & 0.85 & 0.85 & 0.85 & 0.85 \\
\hline Available phosphorus & 0.45 & 0.45 & 0.45 & 0.45 \\
\hline Digestible tryptophan & 0.26 & 0.26 & 0.26 & 0.26 \\
\hline Digestible arginine & 1.23 & 1.23 & 1.93 & 1.50 \\
\hline Digestible lysine & 1.45 & 1.45 & 1.45 & 1.45 \\
\hline Digestible methionine & 0.55 & 0.55 & 0.56 & 0.55 \\
\hline Metab. + Digestible cystine & 0.82 & 0.82 & 0.81 & 0.81 \\
\hline Digestible threonine & 0.91 & 0.91 & 0.91 & 0.91 \\
\hline
\end{tabular}

${ }^{a}$ Nutritional values obtained from the ingredients were recommended by Rostagno et al. (2011). ${ }^{\mathrm{b}}$ Mineral and vitamin supplements provided per kg of feed: $100 \mathrm{mg} \mathrm{Fe,} 10 \mathrm{mg} \mathrm{Cu}, 0.3 \mathrm{mg} \mathrm{Se}, 40 \mathrm{mg} \mathrm{Mn}, 100 \mathrm{mg}$ Zn, $1 \mathrm{mg}$ Co, $1.5 \mathrm{mg}$ I, 9000 IU vit. A, 2250 IU vit.D3, $22.5 \mathrm{mg}$ vit.E, $22.5 \mathrm{mg}$ vit.K3, $2.03 \mathrm{mg}$ vit.B1, $6 \mathrm{mg}$ vit.B2, $3 \mathrm{mg}$ vit.B6, 30 g vit. B12, $0.9 \mathrm{mg}$ folic acid, $14.03 \mathrm{mg}$ pantothenic acid, $30 \mathrm{mg}$ niacin, $0.12 \mathrm{mg}$ biotin, $400 \mathrm{mg}$ choline. 'Washed sand. ${ }^{\mathrm{d}} \mathrm{CD}$ - control diet, composed mainly of corn, soybean meal and dairy product, without supplementation of L-glutamine + glutamic acid and L-arginine; GD - glutamine diet consisting mainly of corn, soybean meal and dairy product supplemented with $1 \%$ L-glutamine + glutamic acid; AD - arginine diet consisting mainly of corn, soybean meal and dairy product supplemented with $1 \%$ L-arginine; and GAD - glutamine + arginine diet consisting mainly of corn, soybean meal and dairy product supplemented with $0.5 \%$ L-glutamine + glutamic acid and $0.5 \%$ L-arginine. 
Table II. Formulation and chemical composition of experimental diets used for piglets weighing 9-15 $\mathrm{kg}^{\mathrm{a}}$.

\begin{tabular}{|c|c|c|c|c|}
\hline \multirow[b]{2}{*}{ Ingredients (kg) } & \multicolumn{4}{|c|}{ Experimental diets $^{\mathrm{d}}$} \\
\hline & CD & GD & AD & GAD \\
\hline Corn meal & 49.98 & 50.33 & 55.00 & 52.67 \\
\hline Soybean meal & 33.28 & 31.71 & 27.63 & 29.67 \\
\hline Whey powder & 7.00 & 7.00 & 7.00 & 7.00 \\
\hline Soybean oil & 5.00 & 5.00 & 5.00 & 5.00 \\
\hline Calcitic lime & 0.67 & 0.67 & 0.69 & 0.68 \\
\hline Dicalcium phosphate & 1.60 & 1.62 & 1.64 & 1.63 \\
\hline L-glutamine + glutamic acid & 0.00 & 1.00 & 0.00 & 0.50 \\
\hline L-arginine & 0.00 & 0.00 & 1.00 & 0.50 \\
\hline L-lysine HCL & 0.45 & 0.50 & 0.62 & 0.56 \\
\hline DL-methionine & 0.17 & 0.19 & 0.22 & 0.21 \\
\hline L-tryptophan & 0.01 & 0.02 & 0.04 & 0.03 \\
\hline L-threonine & 0.18 & 0.20 & 0.26 & 0.23 \\
\hline Mineral and vitamin suppl. ${ }^{b}$ & 0.50 & 0.50 & 0.50 & 0.50 \\
\hline Common salt & 0.33 & 0.33 & 0.33 & 0.33 \\
\hline BHT & 0.02 & 0.02 & 0.02 & 0.02 \\
\hline Inert $^{c}$ & 0.78 & 0.87 & 0.01 & 0.44 \\
\hline Total & 100.0 & 100.0 & 100.0 & 100.0 \\
\hline \multicolumn{5}{|c|}{ Calculated values (\%) } \\
\hline Metabolizable energy (Mcal/kg) & 3.375 & 3.375 & 3.375 & 3.375 \\
\hline Crude protein & 21.00 & 21.00 & 21.00 & 21.00 \\
\hline Calcium & 0.82 & 0.82 & 0.82 & 0.82 \\
\hline Available phosphorus & 0.45 & 0.45 & 0.45 & 0.45 \\
\hline Digestible tryptophan & 0.23 & 0.23 & 0.23 & 0.23 \\
\hline Digestible arginine & 1.24 & 1.19 & 2.04 & 1.62 \\
\hline Digestible lysine & 1.33 & 1.33 & 1.33 & 1.33 \\
\hline Digestible methionine & 0.46 & 0.46 & 0.48 & 0.47 \\
\hline Metab.+ Digestible cystine & 0.74 & 0.74 & 0.74 & 0.74 \\
\hline Digestible threonine & 0.83 & 0.83 & 0.83 & 0.83 \\
\hline
\end{tabular}

${ }^{a}$ Nutritional values obtained from the ingredients were recommended by Rostagno et al. (2011). ${ }^{\mathrm{b}}$ Mineral and vitamin supplements provided per kg of feed: $100 \mathrm{mg} \mathrm{Fe}, 10 \mathrm{mg} \mathrm{Cu}, 0.3 \mathrm{mg} \mathrm{Se}, 40 \mathrm{mg} \mathrm{Mn}, 100 \mathrm{mg} \mathrm{Zn,} 1 \mathrm{mg} \mathrm{Co}, 1.5 \mathrm{mg}$ I, 9000 IU vit. A, 2250 IU vit.D3, $22.5 \mathrm{mg}$ vit.E, $22.5 \mathrm{mg}$ vit.K3, $2.03 \mathrm{mg}$ vit.B1, $6 \mathrm{mg}$ vit.B2, $3 \mathrm{mg}$ vit.B6, 30 g vit. B12, $0.9 \mathrm{mg}$ folic acid, $14.03 \mathrm{mg}$ pantothenic acid, $30 \mathrm{mg}$ niacin, $0.12 \mathrm{mg}$ biotin, $400 \mathrm{mg}$ choline. 'Washed sand. ${ }^{\mathrm{d}} \mathrm{CD}$ - control diet, composed mainly of corn, soybean meal and dairy product, without supplementation of L-glutamine + glutamic acid and L-arginine; GD - glutamine diet consisting mainly of corn, soybean meal and dairy product supplemented with $1 \%$ L-glutamine + glutamic acid; AD - arginine diet consisting mainly of corn, soybean meal and dairy product supplemented with $1 \%$ L-arginine; and GAD - glutamine + arginine diet consisting mainly of corn, soybean meal and dairy product supplemented with $0.5 \%$ L-glutamine + glutamic acid and $0.5 \%$ L-arginine. 
Table III. Formulation and chemical composition of experimental diets used for piglets weighing $15-30 \mathrm{~kg}^{\mathrm{a}}$.

\begin{tabular}{|c|c|c|c|c|}
\hline \multirow[b]{2}{*}{ Ingredients (kg) } & \multicolumn{4}{|c|}{ Experimental diets $^{d}$} \\
\hline & CD & GD & AD & GAD \\
\hline Corn meal & 64.54 & 67.19 & 70.05 & 68.61 \\
\hline Soybean meal & 28.94 & 29.93 & 23.21 & 25.07 \\
\hline Soybean oil & 1.82 & 1.05 & 1.65 & 1.35 \\
\hline Calcitic lime & 0.55 & 0.56 & 0.58 & 0.57 \\
\hline Dicalcium phosphate & 1.58 & 1.59 & 1.62 & 1.60 \\
\hline L-glutamine + glutamic acid & 0.00 & 1.00 & 0.00 & 0.50 \\
\hline L-arginine & 0.00 & 0.00 & 1.00 & 0.50 \\
\hline L-lysine $\mathrm{HCL}$ & 0.39 & 0.45 & 0.56 & 0.50 \\
\hline DL-methionine & 0.09 & 0.11 & 0.14 & 0.12 \\
\hline L-tryptophan & 0.00 & 0.00 & 0.02 & 0.01 \\
\hline L-threonine & 0.12 & 0.15 & 0.20 & 0.18 \\
\hline Mineral and vitamin suppl. ${ }^{\text {b }}$ & 0.50 & 0.50 & 0.50 & 0.50 \\
\hline Common salt & 0.40 & 0.40 & 0.41 & 0.40 \\
\hline BHT & 0.02 & 0.02 & 0.02 & 0.02 \\
\hline Inert $^{\mathrm{c}}$ & 1.00 & 0.00 & 0.00 & 0.00 \\
\hline Total & 100.0 & 100.0 & 100.0 & 100.0 \\
\hline \multicolumn{5}{|c|}{ Calculated values (\%) } \\
\hline Metabolizable energy (Mcal/kg) & 3.230 & 3.230 & 3.230 & 3.230 \\
\hline Crude protein & 19.2 & 19.2 & 19.2 & 19.2 \\
\hline Calcium & 0.72 & 0.72 & 0.72 & 0.72 \\
\hline Available phosphorus & 0.40 & 0.40 & 0.40 & 0.40 \\
\hline Digestible tryptophan & 0.19 & 0.19 & 0.19 & 0.19 \\
\hline Digestible arginine & 1.13 & 1.09 & 1.94 & 1.51 \\
\hline Digestible lysine & 1.14 & 1.14 & 1.14 & 1.14 \\
\hline Digestible methionine & 0.37 & 0.37 & 0.37 & 0.37 \\
\hline Metab. + Digestible cystine & 0.64 & 0.64 & 0.64 & 0.64 \\
\hline Digestible threonine & 0.72 & 0.72 & 0.72 & 0.72 \\
\hline
\end{tabular}

${ }^{a}$ Nutritional values obtained from the ingredients were recommended by Rostagno et al. (2011). ${ }^{\mathrm{b}}$ Mineral and vitamin supplements provided per kg of feed: $100 \mathrm{mg} \mathrm{Fe}, 10 \mathrm{mg} \mathrm{Cu}, 0.3 \mathrm{mg} \mathrm{Se}, 40 \mathrm{mg} \mathrm{Mn}, 100 \mathrm{mg} \mathrm{Zn,} 1 \mathrm{mg}$ Co, $1.5 \mathrm{mg}$ I, 9000 IU vit. A, 2250 IU vit.D3, $22.5 \mathrm{mg}$ vit.E, $22.5 \mathrm{mg}$ vit.K3, $2.03 \mathrm{mg}$ vit.B1, $6 \mathrm{mg}$ vit.B2, $3 \mathrm{mg}$ vit.B6, 30 g vit. B12, $0.9 \mathrm{mg}$ folic acid, $14.03 \mathrm{mg}$ pantothenic acid, $30 \mathrm{mg}$ niacin, $0.12 \mathrm{mg}$ biotin, $400 \mathrm{mg}$ choline. 'Washed sand. ${ }^{\mathrm{d}} \mathrm{CD}$ - control diet, composed mainly of corn, soybean meal and dairy product, without supplementation of L-glutamine + glutamic acid and L-arginine; GD - glutamine diet consisting mainly of corn, soybean meal and dairy product supplemented with $1 \%$ L-glutamine + glutamic acid; AD - arginine diet consisting mainly of corn, soybean meal and dairy product supplemented with $1 \%$ L-arginine; and GAD - glutamine + arginine diet consisting mainly of corn, soybean meal and dairy product supplemented with $0.5 \%$ L-glutamine + glutamic acid and $0.5 \%$ L-arginine. 


\section{Growth performance and sample collection}

For the determination of the performance variables, the animals and the feed provided were weighed at the beginning and end of each experimental period, as were the leftovers, to obtain the average daily intake, the average daily weight gain and feed conversion. The performance results were analyzed in the following periods: I - 28 to 35 days of age; II - 28 to 42 days of age; and III - 28 to 49 days of age. Fecal scores of the piglets were recorded in the first 21 days of the experimental period. Twice a day, stool consistency was checked at 8:00 a.m. and 5:00 p.m. by visual analysis, according to the following scores: 1 - normal feces; 2 pasty feces; and 3 - watery feces. Scores of 1 or 2 were considered non-diarrheal stools, and a score of 3 was considered a diarrheal stool. These analyses were always made by the same observer.

\section{Morphometric structures and}

\section{immunohistochemistry of the small intestine}

At the end of the third rearing period (49 days of age), one animal from each experimental unit was fasted for 12 hours and then sent to the slaughterhouse of the CCHSA/UFPB and humanely slaughtered for collection of intestinal segments. Samples $( \pm 3 \mathrm{~cm})$ were taken from the initial portion of the duodenum and the middle portion of the jejunum to study the morphometric structures of the small intestine. The intestinal segments (duodenum and jejunum) were fixed in Metacarn solution (60\% methanol, 30\% chloroform, $10 \%$ acetic acid) for 12 hours until transfer to $70 \%$ alcohol. The samples were processed histologically according to a standard protocol (Ramos et al. 2011) in the Laboratory of Histology of the Graduate Program in Animal Science of the Center for Agricultural Sciences, Areia, Campus/UFPB and stained with hematoxylin-eosin (morphometry) and periodic acid of Schiff(PAS) (morphometry of goblet cells). For the reading and scanning of histological slides, an Olympus BX60 light microscope and Zeiss Axion camera coupled with a computer were used together with the Motic Image Plus 2.0 digital image capture program. The following morphometric measurements were taken: villus height (VH), crypt depth (CD), villus thickness (VT), mucosa thickness (MT), villus density per area (VD) and goblet cell count (GC) according to Moreira Filho et al. (2015) with modifications; and absorptive area (villus height $\mathrm{x}$ villi width) and villus density per area (determined by total villi in an area of $12,500 \mu \mathrm{m}^{2}$, with the total villi being corrected to $10,000 \mu \mathrm{m}$ ).

The proliferative activity of the intestinal cells of the duodenal crypts was analyzed by immunohistochemistry for antibody to proliferating cell nuclear antigen (anti-PCNA). After rehydration of the slides, endogenous peroxidase was blocked with three hydrogen peroxide baths for 10 minutes each, and the slides were then washed three times with phosphate-buffered saline (PBS) for 3 minutes each. Antigen unmasking was performed with citrate buffer ( $\mathrm{pH} \mathrm{6.0)}$ ) for 10 minutes in the microwave, followed by waiting 20 minutes for the temperature to drop. Non-specific proteins were blocked with incubation in Protein Block (DAKO) for 30 minutes. The slides were then washed again in PBS and incubated at $4^{\circ}$ Covernight with the antibody (SC-7907, Santa Cruz, USA) diluted 1:200 in PBS. In all slides there was a negative control without the primary antibody. The next day, the biotinylated secondary antibody was placed on the slides for 15 minutes, followed by incubation in streptavidin-peroxidase complex (DAKO-LSAB) for 30 minutes. The positive cells were labeled by the DAB chromogen (DAKO) for 5 minutes and counterstained with hematoxylin. The photomicrographs were taken with the Zeiss KS-400 program under an Olympus BX60 microscope and AxioCam camera.

One slide per animal slaughtered (eight animals per treatment) was used, and the duodenal crypts were randomly measured to a total of 10,000 $\mu \mathrm{m}$ per treatment. Such epithelia 
were quantified for the number of anti-PCNA cells. All readings were performed by the same evaluator using a 40x objective.

\section{Statistical analysis}

Data were subjected to analysis of variance (ANOVA) using the GLM (General Linear Models) procedure in the SAS ${ }^{\oplus}$ statistical software and the means were compared by Tukey's test at a significance level of $5 \%$. The normality of the errors was tested by the Cramer-von Mises test, according to Everitt (1998). Non-parametric statistics was used to evaluate the incidence of diarrhea, and the means were compared by the Kruskall-Wallis test (significance level, 5\%).

\section{RESULTS}

The results of productive performance are presented in Table IV. For the period from 28 to 35 days of age, supplementation with $1 \%$ L-arginine $(P<0.05)$ increased the weight gain of the animals compared with the control group and the amino acid combination group (DGA), but DA and DG did not differ in weight gain. Feed conversion was higher in the DGA and DA groups than in the DG group.

At 28 to 42 days of age, the highest weight gain was observed $(P=0.0139)$ in the $D G$ group, which differed from the DA and DGA groups but not from the DC group. The best feed conversion was observed in the DA and DG groups, whereas the worst feed conversion was observed in the DGA and DC groups.

Table IV. Effects of the addition of L-glutamine + glutamic acid or L-arginine to the diet of newly weaned piglets on average daily weight gain (ADG), average daily intake (ADI), feed conversion (FC) and incidence of diarrhea.

\begin{tabular}{|c|c|c|c|c|c|c|}
\hline & \multicolumn{4}{|c|}{ Experimental diets $^{\mathrm{a}}$} & \multirow[b]{2}{*}{$\mathrm{CV}^{\mathrm{b}}(\%)$} & \multirow[b]{2}{*}{ P-value } \\
\hline & $C D$ & GD & $A D$ & GAD & & \\
\hline \multicolumn{7}{|c|}{28 to 35 days of age } \\
\hline ADG (g) & $237.67^{b}$ & $258.46^{a b}$ & $290.25^{a}$ & $231.43^{b}$ & 23.96 & $0.0369^{*}$ \\
\hline ADI (g) & 289.85 & 310.85 & 290.18 & 291.35 & 14.57 & 0.7197 \\
\hline $\mathrm{FC}(\mathrm{g} / \mathrm{g})$ & $1.30^{\mathrm{ab}}$ & $1.49^{a}$ & $1.22^{b}$ & $1.29^{b}$ & 16.05 & $0.0124^{*}$ \\
\hline \multicolumn{7}{|c|}{28 to 42 days of age } \\
\hline ADG (g) & $244.64^{\mathrm{ab}}$ & $260.71^{a}$ & $235.70^{b}$ & $237.50^{b}$ & 16.83 & $0.0139 *$ \\
\hline ADI (g) & 331.58 & 340.40 & 315.33 & 330.46 & 10.09 & 0.5155 \\
\hline $\mathrm{FC}(\mathrm{g} / \mathrm{g})$ & $1.47^{\mathrm{ab}}$ & $1.39^{b}$ & $1.35^{b}$ & $1.49^{a}$ & 16.21 & $0.0236^{*}$ \\
\hline \multicolumn{7}{|c|}{28 to 49 days of age } \\
\hline ADG (g) & $288.01^{\mathrm{ab}}$ & $291.10^{a}$ & $270.01^{b}$ & $261.22^{b}$ & 12.93 & $0.0056^{\star}$ \\
\hline ADI (g) & 397.70 & 403.46 & 382.48 & 388.77 & 9.95 & 0.7179 \\
\hline $\mathrm{FC}(\mathrm{g} / \mathrm{g})$ & $1.38^{\mathrm{ab}}$ & $1.37^{b}$ & $1.34^{b}$ & $1.48^{a}$ & 8.41 & $0.0227^{*}$ \\
\hline \multicolumn{7}{|c|}{ Incidence of diarrhea } \\
\hline Score-3 (\%) & $17.23^{a}$ & $11.31^{b}$ & $15.48^{a b}$ & $16.07^{\mathrm{a}}$ & - & $<0.001$ \\
\hline
\end{tabular}

${ }^{a} \mathrm{CD}$ - control diet, composed mainly of corn, soybean meal and dairy product, without supplementation of L-glutamine + glutamic acid and L-arginine; GD - glutamine diet consisting mainly of corn, soybean meal and dairy product supplemented with $1 \%$ L-glutamine + glutamic acid; AD - arginine diet consisting mainly of corn, soybean meal and dairy product supplemented with $1 \%$ L-arginine; and GAD - glutamine + arginine diet consisting mainly of corn, soybean meal and dairy product supplemented with $0.5 \%$ L-glutamine + glutamic acid and $0.5 \%$ L-arginine. ${ }^{b}$ Variance Coeficent *Means followed by different letters in the same row indicate significant differences. 
In the period from 28 to 49 days of age, weight gain was greater in the DG group than in the DA and DGA groups $(P=0.0056)$ but did not differ from the DC group. The best feed conversion was observed when the animals were fed the DG and DA diets. No significant effects ( $P>0.05$ ) were observed for feed intake at any of the analyzed periods.

The lowest incidence of diarrhea was observed in the DG group, and the highest incidence of diarrhea was observed in the DC and DGA groups (Table IV).
Table $V$ shows the results for villus height, villus/crypt ratio, mucosa thickness, villus thickness, absorptive area, villus density per area and cell index in the duodenum. The highest villus height was observed in the DGA group ( $P$ $<0.05$ ). The lowest villus height was observed in the DC group. The ratio of villus height to crypt depth was highest in the DA group and lowest in the DC group.

The highest mucosa thickness in the duodenum was observed in the DGA group; this diet did not differ from DG or DA but did differ from DC. The highest villus thickness

Table V. Mean villus height (VH), crypt depth (CD) and villus height:crypt depth ratio (VH/CD), mucosa thickness (MT), villus thickness (VT), absorptive area (AA), villus density per area (VD), goblet cell count (GC) and anti-PCNA ${ }^{+}$ cell count of the duodenum and jejunum of piglets fed L-glutamine + glutamic acid and L-arginine.

\begin{tabular}{|c|c|c|c|c|c|c|}
\hline & \multicolumn{4}{|c|}{ Experimental diets $^{\mathrm{a}}$} & \multirow[b]{2}{*}{$C^{b}(\%)$} & \multirow[b]{2}{*}{ P-value } \\
\hline & $C D$ & GD & $A D$ & GAD & & \\
\hline \multicolumn{7}{|c|}{ Duodenum } \\
\hline $\mathrm{VH}(\mu \mathrm{m})$ & $340.28^{b}$ & $371.31^{\mathrm{ab}}$ & $425.80^{a b}$ & $449.34^{a}$ & 14.88 & $0.0051^{*}$ \\
\hline $\mathrm{CD}(\mu \mathrm{m})$ & 334.55 & 329.03 & 304.40 & 345.88 & 13.34 & 0.7323 \\
\hline $\mathrm{VH} / \mathrm{CD}$ & $1.06^{b}$ & $1.13^{\mathrm{ab}}$ & $1.40^{\mathrm{a}}$ & $1.30^{\mathrm{ab}}$ & 18.67 & $0.0376^{\star}$ \\
\hline MT $(\mu \mathrm{m})$ & $674.83^{b}$ & $700.34^{a b}$ & $730.19^{a b}$ & $795.23^{a}$ & 10.51 & $0.0277^{*}$ \\
\hline $\mathrm{VT}(\mu \mathrm{m})$ & $165.54^{b}$ & $178.43^{a}$ & $146.90^{b}$ & $185.95^{a}$ & 10.78 & $0.0019 *$ \\
\hline $\mathrm{AA}\left(\mu \mathrm{m}^{2}\right)$ & $57.769^{b}$ & $66.844^{b}$ & $62.249^{b}$ & $84.626^{a}$ & 21.43 & $0.0074^{*}$ \\
\hline VD (villus/ $\left.\mu m^{2}\right)$ & $87.62^{b}$ & $116.75^{a}$ & $123.62^{a}$ & $116.62^{a}$ & 10.21 & $0.0407^{*}$ \\
\hline GC & $9.17^{c}$ & $11.01^{b}$ & $14.18^{a}$ & $11.42^{b}$ & 11.16 & $0.0350 *$ \\
\hline Anti-PCNA ${ }^{+}$ & $8.99^{c}$ & $12.91^{\mathrm{a}}$ & $10.62^{b}$ & $10.16^{b}$ & 14.20 & $<0.001$ \\
\hline \multicolumn{7}{|c|}{ Jejunum } \\
\hline $\mathrm{VH}(\mu \mathrm{m})$ & 340.63 & 368.90 & 345.88 & 375.15 & 13.85 & 0.4410 \\
\hline $\mathrm{CD}(\mu \mathrm{m})$ & 276.56 & 264.64 & 257.02 & 250.58 & 13.86 & 0.5319 \\
\hline $\mathrm{VH} / \mathrm{CD}$ & 1.23 & 1.39 & 1.34 & 1.50 & 17.11 & 0.1666 \\
\hline $\mathrm{MT}(\mu \mathrm{m})$ & 617.19 & 633.54 & 602.09 & 625.73 & 13.16 & 0.8264 \\
\hline $\mathrm{VT}(\mu \mathrm{m})$ & $131.57^{b}$ & $146.26^{\mathrm{ab}}$ & $153.51^{\mathrm{ab}}$ & $169.40^{a}$ & 11.31 & $0.0021^{*}$ \\
\hline $\mathrm{AA}\left(\mu \mathrm{m}^{2}\right)$ & $44.955^{b}$ & $52.933^{\mathrm{ab}}$ & $53.198^{\mathrm{ab}}$ & $63.628^{a}$ & 16.03 & $0.0031^{*}$ \\
\hline VD (villus/ $\left.\mu m^{2}\right)$ & $117.37^{b}$ & $132.75^{a}$ & $130.25^{a}$ & $114.00^{b}$ & 5.65 & $0.0441^{*}$ \\
\hline $\mathrm{GC}$ & 11.14 & 12.17 & 12.48 & 11.45 & 15.88 & 0.5356 \\
\hline
\end{tabular}

${ }^{a} \mathrm{CD}$ - control diet, composed mainly of corn, soybean meal and dairy product, without supplementation of L-glutamine + glutamic acid and L-arginine; GD - glutamine diet consisting mainly of corn, soybean meal and dairy product supplemented with $1 \%$ L-glutamine + glutamic acid; AD - arginine diet consisting mainly of corn, soybean meal and dairy product supplemented with $1 \%$ L-arginine; and GAD - glutamine + arginine diet consisting mainly of corn, soybean meal and dairy product supplemented with

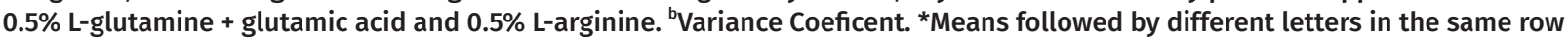
indicate significant differences. 
and absorptive area were observed in the DGA group as well. The DA, DG, and DGA groups all had similar villus density per area values, which were significantly greater than that of the DC group. The highest absorptive area was observed when $0.5 \%$ L-glutamine + glutamic acid and 0.5\% L-arginine were added to the diet.

The addition of the amino acids in the feed, in combination or separately, results in a higher villus density per area than the control diet the highest goblet cell count was found in the AD group, whereas $C D$ had the lowest number of goblet cells.

In the jejunum, significant effects $(P<0.05)$ were observed for villus thickness, absorptive area, and villus density per area, with the highest villus thickness being observed in the DGA group and the lowest in the DC group. The highest absorptive area and the highest villus density per area were also observed in the DGA group.

The highest number of cells labeled with anti-PCNA ${ }^{+}$was observed in the DG group, followed by the DA, DGA, and DC groups (Fig. 1).

\section{DISCUSSION}

The results of this study demonstrate that the action of the amino acids L-glutamine + glutamic
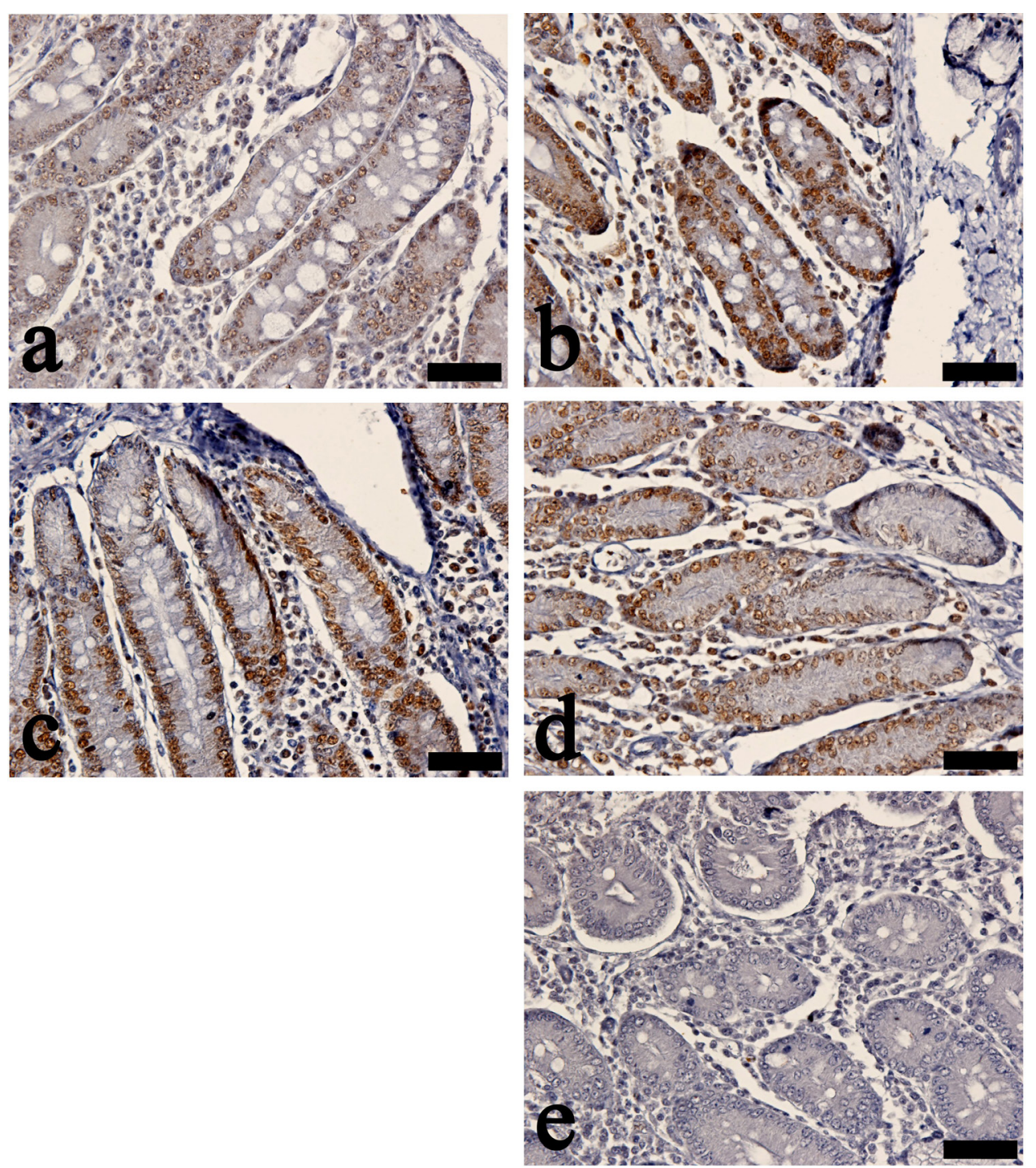

Figure 1.

Photomicrographs of the duodenum of newly weaned piglets fed a diet containing L-glutamine + glutamic acid and L-arginine in combination or separately, demonstrating antiPCNA ${ }^{+}$cells.

a) Anti-PCNA ${ }^{+}$cells from piglets fed a control diet without the addition of amino acids; b) Anti-PCNA ${ }^{+}$cells from piglets fed a control diet with the addition of $1 \%$ L-glutamine + glutamic acid; c) Anti-PCNA ${ }^{+}$cells from piglets fed a control diet with the addition of $1 \%$ L-arginine; d) Anti-PCNA ${ }^{+}$cells from piglets fed a control diet with the addition of $0.5 \%$ L-glutamine + glutamic acid and $0.5 \%$ L-arginine; e) Negative control (without primary antibody). Bar: 40 micrometers. 
acid and L-arginine on weight gain and feed conversion are related to the stage of life of the piglets, with L-arginine having an action in the first period analyzed (28 to 35 days of age) and L-glutamine + glutamic acid in the subsequent periods of the nursery stage. Wu et al. (2007) reported that L-arginine is a non-essential amino acid for adult animals and is used for maximum growth in young mammals (including piglets), who have particularly high requirements of this amino acid for growth and metabolic functions, especially during the first days of life. Arginine is an amino acid conditionally essential for piglets. This can be justified because many types of cells use arginine as a precursor to nitric oxide, which is an essential metabolite for several processes, immune response and neurotransmission (Mateo et al. 2008). Thus, arginine is recognized as a functional amino acid with positive aspects in animal nutrition and health (Wu et al. 2015). The authors report that the deficiency of these amino acids in the initial period of life of mammals can lead to problems as growth retardation, impairment of intestinal functions and reduction of the development of the immune system, as well as can interfere in reproductive physiology, as animals require great amounts of these amino acids during pregnancy and lactation. L-glutamine + glutamic acid are important in the development of tissues with rapid turnover, such as the intestinal mucosa, which is important for piglets, since the stress caused by weaning compromises the integrity of the villi of the small intestine and reduces the absorptive area (Hedemann et al. 2006), thus hindering nutrient absorption and, consequently, the weight gain of the animals.

The increase in the weight gain of the animals when their diet is supplemented with the amino acids can also be explained by the results observed in the small intestine morphometric indices, in which supplementation with the two amino acids in combination promoted a higher villus height, mucosa thickness, absorptive area and villus density per area of the duodenum. With an increase in these morphological variables of the gastrointestinal tract, the absorption of nutrients tends to increase.

Negative changes in the intestinal mucosa structure of piglets in the weaning phase are caused by factors inherent to this process, such as the separation of the litter from the mother, insertion of animals in a different physical environment, social interaction with animals from other litters and change in the physical form of the diet. These factors contribute to the decrease in the performance of animals with notable changes in the intestinal epithelium, which impairs the processes of digestion and absorption of nutrients, with possible damage to the intestinal barrier, favoring the entry of pathogenic microorganisms and toxins, which can cause in diarrhea problems, a fact observed in this study, where the highest incidence of diarrhea was observed in those animals that did not receive L-arginine or L-glutamine + glutamic acid in the diet. These animals also had the lowest values of villus height, mucosa thickness, absorptive area and goblet cell count in the duodenum.

The supplementation of $1 \%$ of L-glutamine + glutamic acid in the diet of the animals favored a decrease in the incidence of diarrhea, and in this context, L-glutamine + glutamic acid acts to repair the intestinal mucosa, increasing the enterocyte proliferation rate. That is because this amino is the main metabolite of these cells and in high concentrations is a precursor for the formation of nucleic acids, allowing for an immediate response to increase the proliferative rate of cells without entering other metabolic pathways (Zavarize et al. 2010). These data corroborate those found by Teixeira et al. (2014), who observed a lower incidence of diarrhea 
when 1\% L-glutamine + glutamic acid was added to the diet of weaned piglets at 21 days of age.

L-glutamine + glutamic acid supplementation led to the highest number of anti-PCNA ${ }^{+}$cells in the duodenum. Caldara et al. (2010) suggested that supplementation of $1 \%$ of L-glutamine + glutamic acid in diets of weaned piglets accelerates the proliferation of intestinal mucosa cells, indicating a positive response in the mucosal turnover rate and adaptation of the piglets to weaning, thus leading to the maintenance of epithelial integrity and lower incidence of diarrhea. Anti-PCNA ${ }^{+}$cell count was increased over control by supplementation with the two amino acids separately or in combination. The maintenance of digestive and intestinal absorptive capacity is maintained by the continuous formation of new enterocytes as well as their growth and maturation, which is regulated as they elongate along the crypt-villus axis (Xiong et al. 2015) and which facilitates digestion and nutrient absorption.

In general, the maturation of enterocytes occurs during migration from the crypt to the apical villous zone and is dependent on regulatory substances for cell differentiation. The number and size of villi depend on the number of cells in the mucosa: a larger number of cells results in a larger villus size and, consequently, a greater nutrient-absorptive area (Xi et al. 2012). Supplementation with the two amino acids together or separately probably had the observed healthful effects by promoting increased villus height and lower crypt depth of both intestinal segments (duodenum and jejunum). In this context, L-glutamate and L-arginine present polyamines as a product of their metabolisms, which are essential for the synthesis of DNA and proteins, and act in promoting the proliferation and maturation of enterocytes (Jiao et al. 2015), favoring intestinal health.
These results corroborate those found by Liu et al. (2008), who evaluated the effect of L-arginine supplementation on attenuating intestinal damage induced by Escherichia coli as a trigger of inflammation in newly weaned piglets. The authors found, in the three intestinal segments (duodenum, jejunum and ileum), that the addition of $0.5 \%$ or $1 \%$ L-arginine reduced intestinal morphological damage induced by $E$. coli and decreased the induction of crypt cell proliferation and villus cell apoptosis, in turn increasing the nutrient-absorptive area. Likewise, Lescano et al. (2013), when evaluating different levels of inclusion of L-glutamine + glutamic acid $(0.4 \%, 0.8 \%$ and $1.2 \%)$ in the diet of newly weaned piglets, found that the $0.8 \%$ supplementation improved villus height in the duodenum. It was found that the addition of $1 \%$ of a compound of arginine, glutamine, glutamate and glycine in the piglet diet improved intestinal function and reduced the incidence of diarrhea. In addition, the junction of these amino acids intensified the intestinal expression of antioxidants and tight junction proteins in piglets, thus improving intestinal morphology, the intestinal barrier function (Yi et al. 2018).

These data, however, disagree with those found by Shan et al. (2012): when evaluating the inclusion of $1 \%$ L-glutamine in the diet of weaned piglets at 28 days, they found no difference in the intestinal morphology of the duodenum and jejunum. In a study with arginine supplementation for weaned piglets it was observed that there was a reduction in the depth of the crypts in the jejunum region with or without induced oxidative stress (Zheng et al. 2017).

The results of this study demonstrate the importance of providing energetic alternatives to the intestinal cells of weaned piglets at 28 days and strengthens the need to identify nutritional elements that favor the maintenance and 
intestinal integrity of these animals during the weaning phase, a critical phase for maintenance of the weight gain in the growth phase.

\section{CONCLUSION}

In conclusion, supplementation with L-glutamine + glutamic acid and L-arginine, separately or in combination, depending on the life stage, can be a health-promoting nutritional strategy to improve the productive performance and enhance the integrity of the intestinal mucosa of weaned piglets.

\section{Acknowledgments}

We are grateful to Prof. Dr. Ricardo Romão Guerra (UFPB) for his contribution to the histological analysis of this project. We thank the Coordenação de Aperfeiçoamento de Pessoal de Nivel Superior (CAPES) and Conselho Nacional de Desenvolvimento Científico e Tecnológico (CNPq) for technical and financial support for authors.

\section{REFERENCES}

CALDARA FR, DUCATTI C, BERTO DA, DENADAI JC, GARCIA RG \& FERREIRA VMOS. 2010. Glutamine and carbon turnover of the intestinal mucosa of weaned piglets. R Bras Zootec 39(12): 2664-2669.

DUTTLINGER AW, KPODO KR, SCHINCKEL AP, RICHERT BT \& JOHNSON JS. 2020. Effects of increasing dietary L-glutamine to replace antibiotics on pig health and performance following weaning and transport. Transl Ani Scien 4(3): 1-16.

EVERITT BS. 1998. Cambridge Dictionary of Statistics. Cambridge University Press, 410 p.

FREIRE J, PRATES J, PINHO M, LOPES PA, MEDEIRA M, ALFAIA C, COSTA T, CORRENT E \& CHALVON-DEMERSAY T. 2019. Effect of glutamine and/or cystine on gut health, immunity and redox status in post-weaning piglets. Ener Prot Met Nutri 138 (10): 307-308.

HE Y ET AL. 2019. L-Glutamine Represses the Unfolded Protein Response in the Small Intestine of Weanling Piglets. The J Nutr 149(11): 1904-1910.

HEDEMANN MS, ESKILDSEN M, LAERKE HN, PEDERSEN C, LINDBERG JE, LAURINEN P \& KNUDSEN KEB. 2006. Intestinal morphology and enzymatic activity in newly weaned pigs fed contrasting fiber concentrations and fiber properties. J Anim Sci 84(6): 1375-1386.

J FJ, WANG LX, YANG HS, HU A \& YIN YL. 2019. Review: The roles and functions of glutamine on intestinal health and performance of weaning pigs. Anim 13(11): 2727-2735.

JIAO N, ZHENLONG W, YUN J, BIN W, ZHAOLAI D \& GUOYAO W. 2015. L-Glutamate Enhances Barrier and Antioxidative Functions in Intestinal Porcine Epithelial Cells. J Nutrit 145(10): 2258-2264.

LESCANO D, ALBINO L, HANNAS M, SALGUEIRO S, KUTSCHENKO M, NOGUEIRA E \& ROSTAGNO H. 2013. Evaluation of dietary glutamic acid plus glutamine levels on the growth performance of piglets. J Anim Sci 91(2): 107.

LIU H, WANG C, GU X, ZHAO J, NIE C, ZHANG W \& MA X. 2020. Dietary Montmorillonite Improves the Intestinal Mucosal Barrier and Optimizes the Intestinal Microbial Community of Weaned Piglets. Front Microbiol 11: 1-14.

LIU Y, HUANG J, HOU Y, ZHU H, ZHAO S, DING B, YIN Y, YI G, SHI J \& FAN W. 2008. Dietary arginine supplementation alleviates intestinal mucosal disruption induced by Escherichia coli lipopolysaccharide in weaned pigs. Br J Nutr 100(3): 552-560.

MATEO RD, WU GH, MOON HK, CARROLL JA \& KIM SW. 2008. Effects of dietary arginina supplementation during gestation and lactation on the performance of lactation primiparous sows and nursing piglets. J Anim Sci 86(4): 827-835.

MOREIRA FILHO ALBM, OLIVEIRA CJB, OLIVEIRA HB, CAMPOS DB, GUERRA RR, COSTA FGP \& GIVISIEZ PEN. 2015. High Incubation Temperature and Threonine Dietary Level Improve Ileum Response Against Post-Hatch Salmonella Enteritidis Inoculation in Broiler Chicks. PLOS ONE 10(7): e0131474.

MOU Q, YANG H, LONG Y \& HUANG PF. 2019. Amino Acids Influencing Intestinal Development and Health of the Piglets. Anim 9(6): 2-11.

RAMOS AH, SANTOS LM, MIGLINO MA, PERES JÁ \& GUERRA RR. 2011. Biometria, histologia e morfometria do sistema digestório do cachorro-do-mato (Cerdocyon thous) de vida livre. Biotemas 24(4): 111-119.

ROSTAGNO H, ALBINO LFT, DONZELE J, GOMES PC, DE OLIVEIRA RF, LOPES DC, FERREIRA AS, DE TOLEDO BARRETO SL \& EUCLIDES RF. 2011. Tabelas Brasileiras Para Aves e Suínos: Composição de Alimentos e Exigências Nutricionais. 3a ed, Viçosa, MG, UFV, DZO, p. 186.

SHAN Y, SHAN A, LI J \& ZHOU C. 2012. Dietary supplementation of arginine and glutamine enhances the growth and 
intestinal mucosa development of weaned piglets. Livest Sci 150(1): 369-373.

TEIXEIRA AO, NOGUEIRA ET, KUTSCHENKO M, ROSTAGNO HS \& LOPES DC. 2014. Inclusion of glutamine associated with glutamic acid in the diet of piglets weaned at 21 days of age. Rev Bras Saude Prod Anim 15(4): 881-896.

WU G, BAZER FW, DAVIS TA, JAEGER LA, JOHNSON GA, KIM SW, KNABE DA, MEININGER CJ, SPENCER TE \& YIN Y-L. 2007. Important roles for the arginine family of amino acids in swine nutrition and production. Livest Sci 112(1): 8-22.

WU X, RUAN Z, GAO Y, YIN Y, ZHOU X, WANG L, GENG M, HOU Y \& WU G. 2015. Dietary supplementation with L-arginine or $\mathrm{N}$-carbamyl glutamate enhances intestinal growth and heat shock protein-70 expression in weanling pigs fed a corn- and soybean meal-based diet. Amino Acids 39(3): 831-839.

XI P, JIANG Z, DAI Z, LI X, YAO K, ZHENG C, LIN Y, WANG J \& WU G. 2012. Regulation of protein turnover by L-glutamine in porcine intestinal epithelial cells. J Nutr Biochem 23(8): 1012-1017.

XIONG X, TAN B, SONG M, JI P, KIM K, YIN Y \& LIU Y. 2019. Nutritional Intervention for the Intestinal Development and Health of Weaned Pigs. Front Vet Scien 6: 1-14.

XIONG X, YANG H, TAN B, YANG C, WU M, LIU G, KIM SW, LI T, LI L \& WANG J. 2015. Differential expression of proteins involved in energy production along the crypt-villus axis in earlyweaning pig small intestine. Am J Physiol Gastrointest Liver Physiol 309: G229-G237.

YI D, LI B, HOU Y, WANG L, ZHAO D, CHEN H, WU T, ZHOU Y, DING B \& WU G. 2018. Dietary supplementation with an amino acid blen enhances intestinal function in piglets. Amino Acids 50(8): 1089-1100.

ZAVARIZE KC, MENTEN JF, TRALDI AB, SANTAROSA J \& DA SILVA CL. 2010. Utilização de glutamina na nutrição de monogástricos. Rev Port Cienc Vet 105: 573-576.

ZHENG PET AL. 2017. Arginine metabolism and its protective effects on intestinal health and functions in weaned piglets under oxidative stress induced by diquat. $\mathrm{Br} J$ Nutr 117(11): 1495-1502.

ZOU TD, DENG CX, WANG ZR, YE YL \& YOU JM. 2019. Dietary alanyl-glutamine improves growth performance of weaned piglets through maintaining intestinal morphology and digestion-absorption function. Anim 13(9): 1826-1833.

\section{How to cite}

DA SILVA DRP, PASCOAL LAF, OLIVEIRA AC, MARTINS TDD, DA SILVA JHV, FERNANDES FG \& ALMEIDA JMS. 2022. Addition of L-Glutamine + Glutamic Acid and L-Arginine to the diet of weaned piglets. An Acad Bras Cienc 94: e20201575. DOI 10.1590/0001-3765202220201575.

Manuscript received on October 5, 2020;

accepted for publication on April 5, 2021

DAVID R.P. DA SILVA

https://orcid.org/ 0000-0002-9804-0355

LEONARDO A.F. PASCOAL ${ }^{2}$

https://orcid.org/0000-0002-7225-5251

\section{APARECIDA DA C. OLIVEIRA ${ }^{1}$}

https://orcid.org/0000-0003-4880-7551

TEREZINHA D.D. MARTINS ${ }^{2}$

https://orcid.org/0000-0002-4660-3814

JOSÉ H.V. DA SILVA

https://orcid.org/0000-0001-8605-2829

\section{FLÁVIO G. FERNANDES ${ }^{2}$}

https://orcid.org/0000-0002-3943-3212

JONATHAN M. DOS S. ALMEIDA ${ }^{1}$

https://orcid.org/0000-0003-1729-6680

${ }^{1}$ Programa de Pós-Graduação em Zootecnia, Universidade Federal da Paraíba, PB-079, 58397-000 Areia, PB, Brazil

${ }^{2}$ Universidade Federal da Paraíba, Centro de

Ciências Humanas, Sociais e Agrárias, Rua João

Pessoa, s/n, 58220-000 Bananeiras, PB, Brazil

Correspondence to: Leonardo Augusto Fonseca Pascoal

E-mail:leonardo@cchsa.ufpb.br

\section{Author contributions}

Leonardo Augusto F. Pascoal, David Rwbystanne P. da Silva and Terezinha Domiciano Dantas Martins were responsible for Project management, while David Rwbystanne P. da Silva, Aparecida da C. Oliveira and Flávio G. Fernandes assisted in laboratory assessment of biological samples. Leonardo Augusto F. Pascoal, David Rwbystanne P. da Silva and Flávio G. Fernandes were involved in data collection and laboratory work. Leonardo Augusto F. Pascoal, David Rwbystanne P. da Silva, José Humberto V. da Silva and Jonathan Mádson dos S. Almeida were responsible for writing revisions.

\section{(c) BY}

